\title{
Fruit and Vegetable Contributions to Dietary Mineral Intake in Human Health and Disease
}

\author{
Orville A. Levander \\ Agricultural Research Service, U.S. Department of Agriculture, Human Nutrition \\ Research Center, Beltsville, MD 20705
}

In Mar. 1989. the Diet and Health Committee of the National Research Council recommended that persons should increase their consumption of fruits and vegetables such that five or more onehalf cup servings of a combination of vegetables and fruits, especially green and yellow vegetables and citrus fruits. be eaten daily (National Research Council. 1989a). The basis for this recommendation was the association of diets high in plant foods (whole-grain cereals and legumes as well as fruits and vegetables) with a lower occurrence of coronary heart disease and cancers of the lung. esophagus, and stomach. The committee pointed out that the biochemical mechanisms responsible for these dietary associations are not fully understood, but could be largely accounted for by the following nutritional characteristics: low saturated (and total) fat and cholesterol content. high complex carbohydrate content, and high content of vitamins $\mathrm{A}$ and $\mathrm{C}$.

Relatively little attention has been paid to fruits and vegetables as dietary sources of minerals. This is not particularly surprising since the fruit/vegetable food group is rather poor in many minerals. For example, analytical dietary surveys carried out in Finland (Varo and Koivistoinen. 1980) and in the United States (Pennington et al.. 1984) showed that, with the exception of potassium, the fruit/vegetable group contributed $30 \%$ or less to the total dietary intake of a variety of minerals (Table 1). It is the purpose of this re view to explore further the contribution of fruits and vegetables to dietary mineral intake in human health and disease.
The contribution of fruits and vegetables to the dietary mineral intake of humans

The absolute and relative contributions of fruit and vegetable foods to the dietary intake of various macrominerals are shown in

Table 1. Contribution of fruits and vegetables to dietary intake of minerals.

\begin{tabular}{lcc}
\hline & Total dietary intake from fruits and vegetables $(\%)$ \\
\cline { 2 - 3 } Mineral & United States & Finiand \\
\hline Potassium & 35 & 31 \\
Sodium & 11 & 5 \\
Calcium & 7 & 5 \\
Magnesium & 24 & 18 \\
Phosphorus & 11 & 7 \\
Iron & 16 & 13 \\
Zinc & 11 & 7 \\
Copper & 30 & 22 \\
Manganese & 21 & 21 \\
Selenium & 1 & 2 \\
lodine & 3 & $\cdots$
\end{tabular}

Adapted from Pennington et al. (1984) and Vam and Koivistoinen (1980). 
Table 2. Clearly, this food group furnishes appreciable quantities of potassium, which may be important in the control of hypertension. Based on epidemiologic studies and animal experiments, the National Research Council (1989a) concluded that the risk of stroke-related deaths appears to be inversely related to potassium intake and suggested that a diet providing $\approx 3500 \mathrm{mg}$ of potassium daily might contribute to reduced risk of stroke. On the other hand, the Surgeon Generals Report on Nutrition and Health (Dept. of Health and Human Services. 1988) concluded that the evidence linking a reduction in blood pressure with art increased dietary intake of potassium is as yet too preliminary to recommend an increased intake for the general population for the purpose of hypertension control. At any rate, fruits and vegetables are relatively low in sodium, and a diet low in sodium also may be important in controlling blood pressure. Only about one-tenth of the total dietary intake of sodium comes from this food group. Although some leafy green vegetables may be good sources of calcium, the fruit/vegetable group is. in general, a poor source of this element. furnishing $<10 \%$ of the total dietary intake (Table 2). However, the fruit/veg etable group contributes a fair amount of magnesium, almost onefourth of the total dietary intake.

The contribution of fruit and vegetable foods to the dietary intake of trace minerals (arbitrarily defined as those minerals with recommended daily intakes in the milligram to tens of milligrams range) is shown in Table 3. This food group is generally a poor source of iron, copper and silicon, furnishing only $\approx 10 \%$ of the total dietary intake. On the other hand, fruits and vegetables furnish more than one-fifth the intake of copper and manganese and almost three-fifths of the total boron intake. Boron has recently attracted interest among nutritionists because human studies have shown some connection between this element and the urinary excretion of calcium in postmenopausal women (Nielsen et al., 1987). Additional research is needed to determine whether dietary boron plays any role in bone demineralization and attendant calcium loss in such women.

The contribution of fruit and vegetable foods to the dietary intake of ultratrace minerals (arbitrarily defined as those minerals

Table 2. Contribution of fruit and vegetables to dietary intake for macrominerals.

\begin{tabular}{|c|c|c|c|c|}
\hline Macromineral & $\frac{\text { Dailv dietary int }}{\text { Fruit/vegetable }}$ & $\frac{\mathrm{ke}(\mathrm{mg})}{\text { Total }}$ & $\begin{array}{l}\text { Percent } \\
\text { of total }\end{array}$ & $\begin{array}{l}\text { Recommended } \\
\text { intake ( } \mathrm{mg} / \text { day) }\end{array}$ \\
\hline $\begin{array}{l}\text { Potassium } \\
\text { Sodium } \\
\text { Calcium } \\
\text { Phosphorus } \\
\text { Magnesium }\end{array}$ & $\begin{array}{r}1188 \\
536 \\
80 \\
190 \\
82\end{array}$ & $\begin{array}{r}3394 \\
4875 \\
1146 \\
1727 \\
340\end{array}$ & $\begin{array}{r}35 \\
11 \\
7 \\
11 \\
24\end{array}$ & $\begin{array}{r}1600-3500 \\
500-2400 \\
800 \\
800 \\
350\end{array}$ \\
\hline
\end{tabular}

Recalculated from Pennington et al. (1984): recommended intakes based on adult male values give by the National Research Council (1989b).

Table 3. Contribution of fruit and vegetable foods to dietary intake of trace minerals.

\begin{tabular}{llccc}
\hline $\begin{array}{l}\text { Trace } \\
\text { mineral }\end{array}$ & \multicolumn{2}{c}{$\begin{array}{l}\text { Daily diecary intake (mg) } \\
\text { Fruit/vegetable }\end{array}$} & $\begin{array}{l}\text { Percent } \\
\text { of total }\end{array}$ & $\begin{array}{l}\text { Recommended } \\
\text { intake (mg/day) }\end{array}$ \\
\hline Iron & 2.5 & 19 & 13 & 10 \\
Zinc & 1.1 & 16 & 7 & 15 \\
Copper & 0.37 & 1.7 & 22 & $1.5-3$ \\
Manganese & 1.3 & 6.1 & 21 & $2-5$ \\
Silicon & 3.7 & 29 & 13 & $5-20 ?$ \\
Boron & 1.0 & 1.7 & 59 & $1 ?$ \\
\hline
\end{tabular}

Recalculated from Varo and Koivisroinen (1980); recommended intakes for $\mathrm{Fe} . \mathrm{Zn}, \mathrm{Cu}$, and $\mathrm{Mn}$ based on adult male values given by the National Research Council (1989b); others as suggested by Nielsen (1990). having recommended intakes $<1 \mathrm{mg} \cdot \mathrm{day}^{-1}$ ) is shown in Table 4. Fruits and vegetables contribute relatively little selenium or molybdenum to the total dietary intake (although vegetables from seleniferous areas can be quite rich in selenium. see next section). Fruits and vegetables can, however. furnish about one-fifth of the total di etary intake of chromium and arsenic and one-third of the supply of nickel. Roles for the latter three ultratrace elements in human nutrition are presumed, but additional research is needed to establish their Practical importance.

The contribution of hit and vegetable foods to the dietary intake of toxic minerals is shown in Table 5. this food group can con tribute about one-third of the total intake of cadmium and lead, heavy metals that have long been of ecological concern.

Vegetables as a vehicle for increasing the selenium content of the food supply

Selenium deficiency has been shown to be a predisposing condi tion in the etiology of Keshan disease, a cardiomyopathy affecting primarily children and women of child-bearing age in China (Yang et al.. 1988). Lack of dietary selenium also may be involved in the cause of Kashin-Beck disease, an endemic juvenile osteoarthritis that occurs along the Sine-Siberian border (Levander, 1987). Some animal experiments and epidemiologic studies suggest that seleni um may play a protective role against certain human cancers, although the relationship between dietary selenium intake and the in cidence of cancer remains an open question (Willet and Stampfer, 1988).

Several different techniques have been used in China to increase the selenium intake as a way of preventing Keshan disease: Selenium-containing tablets have been distributed field crops have been sprayed with selenium, and table salt has been fortified with selenium. In Finland, selenium has been added to fertilizers used on grains and forages since 1984. and the serum selenium level in the general population there has increased by $» 50 \%$ (Varo et al., 1988).

Should it be considered desirable to increase the dietary seleni urn intake in other countries, vegetables could be an important com -

Table 4. Contribution of fruit and vegetable foods to dietary intake of ultratrace minerals.

\begin{tabular}{lcccc}
\hline $\begin{array}{l}\text { Ultratrace } \\
\text { mineral }\end{array}$ & $\begin{array}{l}\text { Daily dietary intake }(\mu \mathrm{g}) \\
\text { Fruit/vegetable }\end{array}$ & $\begin{array}{l}\text { Percent } \\
\text { of total }\end{array}$ & $\begin{array}{l}\text { Recommended } \\
\text { intake }(\mu \mathrm{g} / \text { day })\end{array}$ \\
\hline Selenium & 0.5 & 30 & 2 & 70 \\
Chromium & 6.8 & 29 & 23 & $50-200$ \\
Molybdenum & 15 & 120 & 13 & $75-250$ \\
Nickel & 44 & 130 & 34 & $<150 ?$ \\
Arsenic & 12 & 58 & 21 & $15 ?$ \\
\end{tabular}

Recalculated from Varo and Koivistoinen (1980); recommended intakes for $\mathrm{Se}$. $\mathrm{Cu}$. and Mo based on adult male values given by the National Research Council (1989b); others as suggested by Nielsen (1990).

Table 5. Contribution of fruit and vegetable foods to dietary intake of toxic minerals.

\begin{tabular}{lcccc}
\hline $\begin{array}{l}\text { Toxic } \\
\text { mineral }\end{array}$ & $\begin{array}{c}\text { Daily dietary intake }(\mu \mathrm{g}) \\
\text { Fruit/vegetable }\end{array}$ & $\begin{array}{c}\text { Total } \\
\text { Percent } \\
\text { of total }\end{array}$ & $\begin{array}{c}\text { Recommended max. } \\
\text { intake }(\mu \mathrm{g} / \mathrm{day})\end{array}$ \\
\hline Mercury & 0.3 & 5.7 & 5 & 43 \\
Cadmium & 3.8 & 13 & 29 & $57-71$ \\
Lead & 22 & 66 & 33 & 430 \\
\hdashline
\end{tabular}

Recalculated from Varo and Koitistoinen (1980); recommended maximum intakes recalculated from provisional weekly intakes established by $\mathrm{FAO} /$ WHO (1972). 
ponent of such a strategy. Although fruits and vegetables usually contribute little to the total dietary intake of selenium (normally 5\% or less) the selenium content of plant foods varies considerably de pending on the amount of selenium available for uptake from the soil. A variety of vegetables (potato, tomato, carrots, cabbage, and onion) grown in seleniferous soils contained 2 to 3 orders of magni tude more selenium than those grown in nonseleniferous soils (Levander, 1976). Therefore, the potential for increasing dietary se lenium intake by the selenization of vegetables is there. should the scientific evidence warrant taking such a step.

Although selenium has been shown to have beneficial effects on human health in some cases, such as Keshan disease, the desirability of increasing the selenium content of the food supply in general is still uncertain. For example, attempts to enhance the antineoplas tic properties of brussels sprouts against chemically induced cancer in rats by raising the selenium content of this vegetable have been unsuccessful (Stoewsand et al.. 1989). Furthermore, under some experimental conditions, elevated intakes of selenium actually increased rather than decreased the incidence of chemically induced cancer in laboratory animals (Nutrition Reviews. 1989). Thus. in certain situations selenium may be not only ineffective, but also harmful. Public health authorities in various countries will have to use the proper degree of caution when deciding whether or not to add selenium to their national food supplies.

\section{Literature Cited}

Department of Health and Human Services. 1988. The Surgeon General's report on nutrition and health. Government Printing Office, Washington, D.C.

FAO/WHO. 1973, Evaluation of certain food additives and Ihe contaminants mercury, lead and cadmium. World Health Org., Geneva, Switzerland. World Health Org. Tech. Rpt. Ser. 505.

Levander. O.A. 1976. Selenium in foods. Selenium-Tellurium in the Environment. Industrial Health Found., Pittsburgh p. 26-53.

Levander. O.A. 1987. Etiological hypotheses concerning Kashin-Ueck disuse, p. 67-71. In: O.A. Levander (ed.). AIN Symp. Proc. Nutrition '87. American Inst. of Nutrition. Bethesda. Md.

National Research Council. 1989a. Diet and health. National Academy Press, Washington. D.C

National Research Council. 1989b. Recommended dietary allowances. 10th ed. National Academy Press, Washington, D.C

Nielsen. F.H. 1990. Other trace elements. In: M. Brown (ed.). Present knowledge in nutrition. eth ed. Nutrition Found., Washington. DC. (In pxss.)

Nielsen, F.H.. C.D. Hunt, L.M. Mullen. and J.R. Hunt. 1987. Effect of dietary boron on mineral, estrogen and testosterone metabolism in postmenopausal women. FASEB J. 1:394-397.

Nutrition Reviews. 1989. Possible enhancement of carcinogenesis by selenium in an animal rumor model. Nutr. Rev. 47:173-175.

Pennington, J.A.T.. D.B. Wilson, B.F. Harland. and J.E. Vanderveen. 1984. Selected minerals in foods surveys. 1974 to 1981182. J.. Amer. Diet. Assn. 84:771-780.

Stoewsand. G.S.. J.L. Anderson, L. Munson, and D.L Lisk. 1989. Effect of dietary brussels sprouts with increased selenium content on mammary carcinogenesis in the rat. Cancer Lett. 45:43-38.

Varo, P. and P. Loivistoinen. 1980. Mineral element composition of Finnish foods. XII General discussion and nutritional evaluation. Acta Agr. Scand.. Suppl. 22: 165-171.

Varo. P., G. Alfthan, P. Ekholm. A. Aro and P. Koivistoinen. 1988. Selenium intake and serum selenium in Finland: effects of soil fertilization with selenium. Amer. J. Clin. Nutr. 48:324-329.

Willett. W.C. and M.J. Stampfer. 1988. Selenium and cancer. Brit. Med. J. 297:573-574.

Yang. G.. K. Ge. J. Chen and X. Chen. 1988. Selenium-related endemic diseases and the daily selenium requirement of humans. World Rev. Nutr. Diet 55:98-152 